\title{
The development of Index Card Match Model in Learning Eartquake Mitigation in Indonesia
} (A Case Sstudy in SMA Negeri 6 in Kerinci Regency)

\author{
Yeva Lenda Mahyastuti \\ Student of Geography Education Master Program, \\ Faculty of Social Sciences, Universitas Negeri Padang, INDONESIA \\ Email: yevalenda@gmail.com
}

\begin{abstract}
The purposes of this research are(1) Developing Index Card MatchModel in learning earthquake mitigation in Indonesia(2) to now the effectivenes of Index Card Match Model in learning earthquake mitigation in Indonesia(3) Improve students learning outcomes in learning earthquake mitigation in Indonesia a. This research is a $\mathrm{RnD}$ research (research and development) by following the steps suggested by Sugiyono. the study was conducted in SMA Negeri 6 in Kerinci Regency. The sample was determined through simple random sampling. The data was collected by using teacher questionnaire and student questionnaire. the rpoduct to be developed was Index Card Matchyang model implemented in teaching and learning the materials of eartquake mitigation in Indonesia. the model had been validated by model and material experts and then being tesed. The result found that there was a significant difference between students' learning outcomes before and after the development of model. After calculating the data, t-test value was setelah $\operatorname{sig}$ (2-tailed) 0,000. This means, Ho (null Hypothesis) was rejected and H1 (researcher hypothesis) was accepted. in other words, there a significant result of pretest and post test.
\end{abstract}

Keywords: Development, Index Card Match Model, Earthquake mitigation

\section{Introduction}

Natural disasters are an event that can be threatening at any time and cause damage to the environment. Natural disasters can occur in all parts of the world, but the impact will be felt when it happens in a developing country like Indonesia, where earthquake natural disaster is quite common. Indonesia is one of the world's largest natural disaster. Terrible disasters, like earthquakes as if 'very familiar' with life in Indonesia some time lately (Directorate of Volcanology and Disaster Mitigation, Dep ESDM RI, 2005). This is due to the geographical position of Indonesia located at the end of the movement of three global plates, namely Eurasian, Indo-Australian, and Pacific. In this condition, Indonesia can not escape from the disaster that befall it. Indonesians residing in disaster prone areas should seek to understand and have the skills to minimize the possible impact of disasters. Therefore, the need for an understanding of how to overcome natural disaster especially earthquake itself in the subject of geography of earthquake disaster mitigation in Kerinci State Senior High School to detect and anticipate earlier various kinds of disaster or better known as disaster mitigation (Satake et al, 2011), should continue to be socialized to the public.

According to Krisna et al (2008), Mitigation is an action taken to reduce the impact caused by the disaster. The mitigation phase focuses on long-term actions to reduce disaster risks. Mitigation measures consist of structural mitigation and non-structural mitigation. Disaster mitigation should be a priority to be introduced at the earliest possible age, such as the introduction of flood hazards for children (Jackson \& Jacobs, 2008; Mileti, 2008). Oemarmadi (2005) argues that the Indonesian people are already semi-exploited 
with knowledge of the dangers of natural disasters, in particular and subsequently, even all members of the general public, such as fishing families, assessing the hazards of disasters, disaster mitigation, rehabilitation and relocation. Knowledge, understanding, and behavioral skills in preventing, detecting, anticipating disasters can effectively be transformed and socialized (Tanaka \& Jinadasa, 2011). Haifani (2008) formulated several matters concerning disaster risk management in the Yogyakarta earthquake case of 27 May 2006, one of which is disaster education and training needs to be implemented and periodically refreshed, also delivered about the understanding of the source of danger and its potential to the community. This can be done by organizing training, brochures, and pamphlets. With a view to cultivating and improving understanding, awareness and public preparedness for earthquake hazards, so that losses and casualties can be reduced at the time of the incident.

According to Nur (2010), prevention and mitigation are the steps needed to achieve sustainable development. Therefore this needs to be developed starting from the school, home and community levels in general. Earthquake planning readiness should also aim to develop a "Safety Culture" in the general public, so that people are aware of the dangers they face and with their knowledge the community can protect themselves (Hosseini, 2006). The position of the model in teaching is as a teaching aid exists in the methodological component, as one of the learning circles set by the teacher. The level of human thinking follows the stage of development from concrete thinking to abstract thinking, from simple thinking to complex thinking. The use of instructional media is closely related to the stages of thinking as it begins the media of teaching abstract things can be concretized, and complex things can be simplified

Based on the results of preliminary observation is known that there are some obstacles in the implementation of learning, especially in class X. Constraints include: the delivery of unfinished material delivered by teachers in the classroom, the demands of material understanding enough both in theory and practice, and unbalanced mastery of students' theory and practice competencies. This happens because of the lack of innovative learning models that can construct students' ideas and knowledge, combine theory and practice, and optimize the delivery of the material thoroughly so that students can learn independently without waiting for the teacher. The existence of adequate facilities and infrastructure support in SMN 6 Kerinci Regency certainly provides a high enough opportunity for the utilization and management of optimal learning. With regard to it, the need for a model of learning that can help learners in developing competence. One attempt to overcome the obstacles above is to develop and implement the Index Card Match learning model. The learning model of Index Card Match fosters student cooperation in answering questions by matching the index cards in their hands. This learning process is more interesting because students are looking for a partner while learning about a concept and a topic in a fun atmosphere, through this model the students have to do a lot of their tasks to use their broad mind power, examine, ideas, solve problems, and apply what they learn in the eyes of disaster mitigation learning especially the earthquake. Index Card Match learning model can train the mindset of students because with this model students are trained speed of thinking in learning a concept or topic through the search card answer or question card, each student must get the matching card pair by students with their partner other students, by discussing with their partner then the students will be more understanding with the concept of the material being studied, because the learning is done in a pleasant atmosphere it is expected to increase the spirit of student activity in Geography learning about earthquake mitigation in Indonesia in a State Senior High School in Kerinci Regency

Research conducted on the development of Index Card Match model in earthquake disaster mitigation learning in Indonesia State Senior High School Level in KerinciRegency shows the significant difference between teaching without model and teaching using Index Card Match model in earthquake disaster mitigation study Therefore by using Index Card Match model increased level of quality in the process of geographic learning of earthquake mitigation in Indonesia The purpose of this study(1) Developing Index Card Match model in learning Earthquake Mitigation in Indonesia (2) Knowing the 
effectiveness of Index Card Match model in learning Mitigation of earthquake disaster in Indonesia (3) Increasing student learning in studying earthquake disaster mitigation in Indonesia.

\section{Method}

The method used is research and development, which is known as Research And Develeopment (R n D). According to Punaji (2015), the strategy for developing an educational product by Borg and Gall (1983) is also called research and development. Understanding research and development is a process used to develop and validate educational products. The model used in this research and development uses the development model from (Sugiyono, 2014, 409). the determination of sample using simple random sampling then taking the data by using teacher questionnaire and student questionnaire. This research and development uses Pre-Experimental Designs (non-designs) experimental design, and uses the One-Group Pretest-Posttest Design type to know the difference of learning outcomes before using the model and after using the model. Problems that will be first experimented in the test validity and reliability test

\section{Results and Discussion}

In this study developed and implemented the learning with Index Card Match model which refers to several stages, which are planning the learning, implementing the learning, and test the effectiveness of learning with Index Card Match model.

\section{The planning processof the Index Card Match learning model}

Includes the activities of learning device planning, syllabus and learning implementation plan (RPP). The result of learning planning designed to be tested feasibility which then used as guidance of learning activity in implementation phase of Index Card Match learning model at next stage.

\section{Implementation stage is done by experimenting the use of Index Card Match model on earthquake disaster mitigation learning.}

This implementation involves a number of students by using Haryanto (Journal of Education Vol.2: 168), index card match strategy can be used as alternative strategy that is perceived better understand the characteristics of students. The characteristic here is that students love to learn while playing, meaning in the process of teaching and learning, teachers should be able to make students feel interested and happy about the material delivered so that later learning goals can be achieved According to Silberman (2013: 250-251) which has been designed in the learning planning stage with the Index Card Match model done as follows: (1) On a separate index card write a question about whatever is taught in the class, make a question card of the same amount, with half the number of students. (2) On a separate card write the answer to each question. (3) Mix two bunches of cards and shake them several times to get really mixed up. (4) Give one card to one student explain this is a partial matching exercise a student gets a review question and the other receives his or her answer card. Ask students to find their partner, if the couple has paired the paired students to find a seat together (5) tell them not to reveal to other couples what's on their cards). (6) When all the matching pairs have been seated together, have each pair give quizzes to other students by reading aloud their questions and challenging other students to give their answers. Variations include (1) Develop cards containing sentences that are omitted one of them, to be matched with the card that says the missing word (2) Or change the postcard with the question and some answer options. Match each card with a card containing some appropriate answers. When one member of the couple asks the participants, ask them to get some answers from the participants. 


\section{The process of effectiveness of learning model Index Card Match}

The process of effectiveness of learning model Index Card Match in terms of results in the form of student learning outcomes based on daily test scores and facets of the process of questionnaires students about the liveliness and motivation of student learning. Assessment of learning outcomes is seen from the results of student learning both before and after the implementation of learning. While the assessment in terms of questionnaires learned from the student learning involvement in learning, as well as learning motivation seen from the encouragement of students in participation padapembelajaran with Index Model Match mitigation earthquake disaster in Indonesia. Based on the results of learning and the results of questionnaires and learning motivation students will be drawn conclusions about the effectiveness or ineffectiveness of learning with the model of Card Match Card.

\section{Analysis of "Need" Questionnaires}

Questionnaires given to teachers and students of class X in SMA Negeri 6 Kerinci Regency can be concluded that the need for Index Card Match model in learning to motivate students in learning. The researcher then developed Index Card Match model in learning earthquake mitigation in Indonesia which has been validated by the material expert

\section{Experiments on Developing Product}

Implementation of the experiment aims to determine the effectiveness of Index Card Match model in earthquake disaster mitigation learning Problem that will be used for the experiment, previously tested the validity and reliability. Validity and reliability test carried out in SMA Negeri 3 Kerinci Regency in grade X 4 and X 5 with total students 62 students. The number of questions tested is 20 questions that have been adapted to the lattice problem. Once tested the validity and reliability can be used for experiments The research was conducted in class X Students were asked to do pretest, then the researcher carried out the learning process, after which the students were asked to do post test questions. The average value of pre test is 77.5 while the post test is 86,9 . The results of the study were tested using t-test so that the result of sig (2-tailed) 0,000 that Ho is rejected and $\mathrm{H} 1$ accepted means that there is difference of pretest and post test result.

\section{Conclusion}

The planning of learning by using Index Card Match model on earthquake disaster mitigation material is feasible to be used as a guide in the implementation of learning. Judging from the basic consideration of the selection of Index Card Match model, indicating the goals to be achieved, learning materials, students' point of view, effectiveness and efficiency in accordance with the earthquake disaster mitigation learning content. Judging from the components of the learning system shows the objectives, materials, methods, media, and evaluation of Index Card Match model, in accordance with the subject matter of earthquake disaster mitigation learning in Indonesia. From the learning tool component of Index Card Match model, it shows the existence of subject identity, SK, KD, indicator, objectives, time allocation, method, learning activity, assessment, and learning resources in accordance with learning tool component of earthquake disaster mitigation in Indonesia. Index Card Match model in earthquake disaster mitigation learning in Indonesia The development was based on researcher's ideas to develop the Index Card Match model in earthquake disaster mitigation learning in Indonesia. Before developing Index Card Match mode the researcher observed the school that will be the research place. Spread of questionnaires needs both for teachers and for students. The research was carried out at SMPN 6 Kerinci Regency. The development of Index Card Match model is able to motivate student learning process. There are differences in pretest and 
post test results. the use of Index Card Match models is more effective. There is an increase in achievement when learning using Index Card Match model. Proven value of average pre test is 77,5 while the value of post test is 86,9 . The results of the study were tested using t-test so that the result of sig (2-tailed) 0,000 that $\mathrm{Ho}$ is rejected and $\mathrm{H} 1$ accepted means that there is difference of pretest and post test result.

\section{Reference}

Annan, K. (2007). Guiding the United Nations.New York: Infobase Publishing; Former UN Secretary General, April 2000.

Akira Tashiro. (2014). Detection Of Callapsed Buildingd Due To Earthquakes Using A Digital SurFace Model Constructed From Aerial Images. Vol 08.No.01

Arief Budiman. (2012). Pengembangan Aplikasi Mobile Pembelajaran Mitigasi Bencana Gempa Bumi Berbasis Multimedia Seminar Nasional Teknologi Informasi dan Komunikasi 2012 (SENTIKA 2012) ISSN: 2089-9815 Yogyakarta, 10 Maret 2012

Djamarah, Syaiful Bahri. (2002). Psikologi Belajar. Jakarta: Rineka Cipta

Dimyati dan Mudjiono. (2006). Belajar dan Pembelajaran. Jakarta: Rineka Cipta

Direktorat Vulkanologi dan Mitigasi Bencana,Departemen Energi dan SumberdayaMineral. 2005. Gempa Bumi danTsunami. Bandung: Alfa Beta.

E.Florido. (2015). Detecting Precursory Patterns To Enhance Earthquake Prediction In Chile. Volume 76, March 2015, Pages 112-120

Vinda Trinovia, Madewi Mulyanratna. (2013). Penerapan Strategi Index Card Match (Mencari Pasangan Kartu) Dalam Model Pembelajaran Kooperatif Tipe Stad Pada Materi Alat OptikJurnal Inovasi Pendidikan Fisika Vol. 02 No. 03 Tahun 2013, 85 - 88

Gusti Ayu Tri Agustiana. (2010). The Effect of Mitigation Learning Model to Students' Poor Resilience Jurnal Pendidikan dan Pengajaran, Jilid 46, Nomor 2, Juli 2013, hlm.97-105

Gupta, M., Devi, M., \& Pasrija, P. (2012). Achievement Motivation: a Major Factor in Determining Academic Achievement. Asian Journal of Multidimensional Research.Volume 1 Nomor 3

Hosseini, M., Izadkhah, Y, O. (2006). Earthquake disaster risk management planning in schools, Disaster Prevention and Management Vol. 15 No. 4

Haifani, A, M. (2008). Manajemen Resiko Bencana Gempa Bumi (Studi Kasus Gempa Bumi Yogyakarta 27 mei 2006), Seminar Nasional IV SDM Teknologi Nuklir.

Haryanto. (2011). Pengaruh Strategi Pembelajaran Aktif Card Sort dan Index Card Match Terhadap Prestasi Belajar Getaran Dan Gelombang. Vol.2 (2). pp:165-172

Jackson, I \& Jacobs, J. (2008). Major floodhits county, damages many roads. TheBrazil Times.

Khusnaini Fauzi. (2017). Cooperative learning index card match model to improve the result of Qur'an Hadith learningVol. 9, No. 1, 2017:53-73, DOI: 10.18326/mudarrisa.v9i1.53-73

Nur, A, M. (2010). Gempa Bumi, Tsunami dan Mitigasinya , Balai Informasi dan Konservasi Kebumian Karangsambung - LIPI Volume 7 No. 1, Kebumen.

Pribadi, Krishna S,et al.,. (2008). PendidikanSiagaBencana. Bandung: Pusat Mitigasi Bencana ITB

Rohani, Ahmad. (2010). Pengelolaan Pengajaran. Jakarta: PT.Rineka Cipta.

Sanjaya, Wina. (2013). Penelitian Pendidikan: Jenis, Metode, dan Prosedur. Jakarta: Kencana Prenada Media Group

Setyosari, Punaji. (2015). Metode Penelitian: Pendidikan dan Pengembangan. Jakarta:Prendamedia Group

Sugiyono. (2014). Statistika Untuk Penelitian. Bandung: Alfabeta

Silberman, Mel. (2009). Active Learning 101 Strategi Pembelajaran Aktif. Yogyakarta: Insan Madani

Silberman, L. dan Melvin. (2013). Active Learning.Bandung: Nusamedia 
Syukur, Imam Abdul. (2014). Pengaruh Model Pembelajaran Teams Games Tournament Termodifikasi Berbasis Outbound Terhadap Prestasi Belajar Fisika Ditinjau dari Motivasi Belajar. Jurnal Pendidikan dan Kebudayaan, Vol. 20, Nomor 3.

Zahrul umar, Biswajeet Pradhan, Anuar Ahmad. (2014). Earthquake Induced Landslide Susceptibility Maapping Using an Integrated Ensemble Freaquency Ratio And Logistic Regression Models In Wesr Sumatra Province, Indonesia. Volume 116, july 2014. Pages 124-136 